\title{
The effectiveness of oral protein supplementation in malnourished peritoneal dialysis patients
}

\author{
Mehmet Usta $^{1} \oplus$, Alparslan Ersoy $^{2} \oplus$, Yavuz $\operatorname{Ayar}^{1} \oplus$ \\ ${ }^{1}$ Department of Nephrology, Bursa City Hospital, Bursa, Turkey \\ ${ }^{2}$ Department of Nephrology, Bursa Uludağ University School of Medicine, Bursa, Turkey
}

\begin{abstract}
Objectives: Malnutrition is a common problem in chronic renal disease patients during pre-dialysis and dialysis, leading to increased cardiovascular diseases and mortality. This study aimed to evaluate the efficacy of supplemental protein supplementation on malnutrition in peritoneal dialysis patients.

Methods: Eighty-four stable adult peritoneal dialysis patients included in this study. In addition to the standard diets, oral nutritional product (372 calories, $61 \mathrm{~g}$ protein, $30 \mathrm{~g}$ glutamine, and $30 \mathrm{~g}$ arginine/100 g powder sachet twice a day) gave to patients. Before the study and after three months from the supportive therapy; anthropometric measurements with serum urea, creatinine, total protein, albumin, cholesterol, KtV, body mass index was analyzed.

Results: The mean age of peritoneal dialysis patients was 60 (46-78) years. Serum urea levels from $96 \pm 44$ to $109 \pm 42 \mathrm{mg} / \mathrm{dL}$ ( $p=0.007)$, total protein levels from $5.85 \pm 0.68$ to $6.18 \pm 0.66 \mathrm{~g} / \mathrm{dL}(7.8 \%, p=0.007)$, albumin levels increased from $3.02 \pm 0.27$ to $3.32 \pm 0.34 \mathrm{~g} / \mathrm{dL}(11.7 \%, p=0.003)$ increased significantly after an average of $0.43 \mathrm{~g} / \mathrm{kg}$ protein and $178 \mathrm{cal} /$ day energy support.

Conclusions: Albumin is an indicator of malnutrition related mortality. Therefore, using of protein nutritional products in addition to standard treatment may be beneficial for malnourished peritoneal dialysis patients.

Keywords: Peritoneal dialysis, malnutrition, albumin, protein supplementation
\end{abstract}

$\mathbf{N}$ utrition plays an important role in chronic kidney diseases (CKD). The most important reason of protein- energy malnutrition is nutritional deficiency. It is directly related to mortality and morbidity. Inadequate oral intake, metabolic acidosis, chronic inflammation, hormonal and enzymatic changes (such as leptin, parathyroid hormone [PTH], insulin), dietary restriction, gastrointestinal diseases are the main causes of protein energy malnutrition in CKD (Table1). In addition, peritoneal dialysis (PD) patients with abdominal distention and reflux due to the pres- sure of intraabdominal fluid are the most important causes of nutritional disorders. Insulin resistance, metabolic acidosis, vitamin D deficiency, hypercalcemia-hypocalcemia, secondary hyperparathyroidism, hyperphosphatemia, renal anemia, uremic bone diseases, chronic inflammation, intermittent acute diseases should be taken into consideration to prevent malnutrition that affects mortality and morbidity [19].

Therefore, nutritional status and disorders in dialysis patients should be followed carefully and closely. 
In this study, we investigated the presence of protein energy malnutrition in peritoneal dialysis patients and detect it early and correct with short term supportive therapy.

\section{METHODS}

\section{Patients}

Eighty-four stable adult peritoneal dialysis patients evaluated. Patients with malignancy, acutechronic infection or inflammatory disease and patients with normal serum albumin values (over $3.5 \mathrm{~g} / \mathrm{dL}$ ) excluded from the study. Malnutrition detected in $17 \mathrm{pa}-$ tients. Malnutrition assessed by serum albumin and creatinine levels, dietary protein and energy intake and obtained from interviews and follow-up. Serum albumin value below $3.5 \mathrm{~g} / \mathrm{dL}$ or patients with insufficient of oral intake considered to be malnourished. Protein nitrogen appearance, subjective general evaluation and anthropometric measurements used to evaluate nutritional status in patients receiving PD treatment. Oral nutritional product (372 calories, $61 \mathrm{~g}$ protein, $30 \mathrm{~g}$ glutamine, and $30 \mathrm{~g}$ arginine/100 g powder sachet twice a day) gave to patients who detected malnutrition in addition to the standard diets. Before the study and after three months from the supportive therapy; anthropometric measurements with serum urea, creatinine, total protein, albumin, periton equilibrium test (PET), cholesterol, peritoneal dialysis adequacy test $(\mathrm{Kt} / \mathrm{V})$ and body mass index (BMI) evaluated.

\section{Statistical Analysis}

Data analyzed using Statistical Package for the Social Sciences (SPSS) version 21 (IBM Acquires SPSS Inc., Somers, NY, USA). Descriptive statistical methods (mean, median, frequency, standard deviation, ratio) compared with Pearson Chi-square, paired $t$ and Mann Whitney $U$ test used to compare two groups of variables that did not show normal distribution. Differences considered significant if $p<0.05$.

\section{RESULTS}

Mean age of peritoneal dialysis patients was 60 years (46-78). Patients with malnutrition were exam-

\section{Table 1. Causes of protein energy malnutrition in CKD patients}

\begin{tabular}{l}
\hline Reduction in oral intake \\
Diet restriction \\
Metabolic acidosis \\
Inflammation \\
$\begin{array}{l}\text { Hormonal and enzymatic disorders } \\
\text { Erythropoietin, PTH, leptin, insulin, etc. } \\
\text { Gastrointestinal disorders }\end{array}$ \\
\hline
\end{tabular}

$\mathrm{CKD}=$ Chronic kidney disease, $\mathrm{PTH}=$ Parathormone

ined for urea, creatinine, $\mathrm{Kt} / \mathrm{V}$, PET, total protein, albumin, cholesterol, phosphorus, transferrin saturation, BMI, thickness of triceps skin before and after 3 months of supportive therapy. As a result of the PET, 19 patients had high permeability, 25 patients were near high medium permeability, 27 patients were near low medium permeability, and 13 patients were low permeability. In malnourished patients, 11 had low permeability, 4 had near low medium and 1 patient had near high medium and high permeability. In addition to the standard dietary intake, patients evaluated and tested 3 months after supplementation. On average of $0.43 \mathrm{~g} / \mathrm{kg}$ protein and $178 \mathrm{cal} /$ day energy supplementation which results were significant recorded after the support. Serum urea levels from $96 \pm 44$ to $109 \pm 42$ $\mathrm{mg} / \mathrm{dL}(p=0.007)$, total protein levels from $5.85 \pm$ 0.68 to $6.18 \pm 0.66 \mathrm{~g} / \mathrm{dL}(7.8 \%, p=0.007)$, albumin levels from $3.02 \pm 0.27$ to $3.32 \pm 0.34 \mathrm{~g} / \mathrm{dL}(11.7 \%, p$ $=0.003)$ increased significantly. There was no significant change in other parameters. The clinical and laboratory results are summarized in Table 2.

\section{DISCUSSION}

PD, HD and renal transplantation are the renal replacement therapies used for end-stage renal disease patients. The incidence of malnutrition in PD is high [2]. In a study, the prevalence of malnutrition was $42 \%$ in patients receiving with PD treatment, while the prevalence in HD patients was $32 \%$ [3]. In this study, serum total protein and albumin levels were low. Negative nutritional parameters in PD patients are directly related to increased morbidity and mortality as well as 
Table 2. Laboratory and clinical features

\begin{tabular}{lccc}
\hline & Beginning & After 3 months & $\boldsymbol{p}$ value \\
\hline $\mathrm{Kt} / \mathrm{V}$ & $1.96 \pm 0.32$ & $2.01 \pm 0.35$ & 0.224 \\
Serum urea $(\mathrm{mg} / \mathrm{dL})$ & $96 \pm 44$ & $109 \pm 42$ & $\mathbf{0 . 0 0 7}$ \\
Serum creatinine $(\mathrm{mg} / \mathrm{dL})$ & $7.5 \pm 1.76$ & $7.6 \pm 1.96$ & 0.835 \\
Serum total protein $(\mathrm{mg} / \mathrm{dL})$ & $5.85 \pm 0.68$ & $6.18 \pm 0.66$ & $\mathbf{0 . 0 0 7}$ \\
Serum albumin $(\mathrm{g} / \mathrm{dL})$ & $3.02 \pm 0.27$ & $3.32 \pm 0.34$ & $\mathbf{0 . 0 0 3}$ \\
Serum phosphorus $(\mathrm{mg} / \mathrm{dL})$ & $3.98 \pm 1.54$ & $3.58 \pm 1.32$ & 0.186 \\
Total cholesterol $(\mathrm{mg} / \mathrm{dL})$ & $152 \pm 34.8$ & $160 \pm 39.2$ & 0.311 \\
Body mass index $\left(\mathrm{kg} / \mathrm{m}^{2}\right)$ & $21.6 \pm 3.96$ & $21.8 \pm 4.12$ & 0.794 \\
Triceps skinfold $(\mathrm{mm})$ & $10.14 \pm 4.81$ & $10.89 \pm 4.76$ & 0.528 \\
\hline
\end{tabular}

$\mathrm{Kt} / \mathrm{V}=$ peritoneal dialysis adequacy test.

HD. These include low serum albumin, creatinine, body mass index, blood urea nitrogen, subjective global evaluation and nutritional scores. Allow value of serum albumin is considered to be $3.5-4.0 \mathrm{~g} / \mathrm{dl}$, which may increase the relative risk of death as compared to $4.0 \mathrm{~g} / \mathrm{dl}$ or higher. On the other hand, decline in creatinine (an indicator of muscle mass) and ideal weight have also associated with increased risk of death in the patient population $[8,10,11]$. However, it is not clear whether nutritional support is beneficial for PD patients with improvement in these parameters. There are no multicenter and large studies on this subject. In our single-center study, we detected 17 malnutrition patients in total of 84 PD patients (19.5\%). In particular, the main causes of malnutrition in $\mathrm{PD}$ patients are malnutrition, insufficient dialysis, hormone abnormalities and inflammation [12]. Nutritional education should be given to the patients. Treatment of abnormal hormone levels, inflammation and effective dialysis are important in PD patients. When we analyze the daily protein loss in PD, it is about $10 \mathrm{~g}$. Thirty percent of this protein loss is essential amino acids [13-16]. In severe cases of peritonitis, protein loss may increase up to $100 \mathrm{~g}$ per day. Especially infection, inflammation and fluid overload detected in cases with low albumin as a biochemical predictor for malnutrition. These results progress to mortality [17-21]. Similarly, in a study evaluating peritoneal dialysis patients who received protein supplements for six months, malnutrition decreased between $6 \%$ and $28 \%$. In another study, protein catabolism rate was lower and albumin level was higher in malnour- ished patients receiving oral protein supplementation for three months $[20,21]$. Therefore, as in our study, PD patients should be closely monitored for malnutrition and supportive treatment. Total protein and albumin increased significantly with supportive treatment in our patients. We did not detect any peritonitis attacks during the study period. Data on oral nutritional support in PD patients are limited. Patient compliance observed important in oral nutrition therapy. Noncompliance and intolerance found to adversely effect on supportive therapy. In our study, we detected three non-compliance of 17 patients (17.6\%). This data was equivalent to current studies.

\section{CONCLUSION}

Finally; malnutrition is common in peritoneal dialysis patients. PD patients should be followed up frequently and regularly for malnutrition. Particularly at high risk patients with low food intake, infection or inflammation, cardiac overload and anuric status should be monitored more frequently and carefully. In our study, we found significant increase in nutritional indicators, especially albumin, directly related to mortality when supportive therapy was given in addition to patients with malnutrition. But we need more largescale studies.

\section{Authors' Contribution}

Study Conception: MU; Study Design: YA; Supervision: AE; Materials: AE; Data Collection and/or 
Processing: MU, YA; Statistical Analysis and/or Data Interpretation: MU; Literature Review: MU; Manuscript Preparation: MU, YA and Critical Review: AE, YA.

\section{Conflict of interest}

The authors disclosed no conflict of interest during the preparation or publication of this manuscript.

\section{Financing}

The authors disclosed that they did not receive any grant during conduction or writing of this study.

\section{Ethics committee approval}

Ethics committee approval was received. Informed consent obtained from the patients.

\section{REFERENCES}

1. Ma L, Zhao S. Risk factors for mortality in patients undergoing hemodialysis: a systematic review and metaanalysis. Int J Cardiol.2017;238:151-8.

2. Stenvinkel P, Heimbürger O, Lindholm B. Wasting, but not malnutrition, predicts cardiovascular mortality in end-stage renal disease. Nephrol Dial Transplant 2004;19:2181-3.

3. Kopple JD. National Kidney Foundation K/DOQI Work Group. The National Kidney Foundation K/DOQI clinical practice guidelines for dietary protein intake for chronic dialysis patients. Am J Kidney Dis 2001;38(4Suppl1):S68-73.

4. Uhlig K, Macleod A, Craig J, Lau J, Levey AS, Levin A, et al. Grading evidence and recommendations for clinical practice guidelines in nephrology. A position statement from Kidney Disease: Improving Global Outcomes (KDIGO). Kidney Int 2006;70:2058-65.

5. LeveyAS, Eckardt KU, Tsukamoto Y, Levin A, Coresh J, Rossert J, et al. Definition and classification of chronic kidney disease: a position statement from Kidney Disease: Improving Global Outcomes (KDIGO). Kidney Int 2005;67:2089-100.

6. Mak RH, CheungW. Energy homeostasis and cachexia in chronic kidney disease. Pediatr Nephrol 2006;21:1807-14.

7. LindholmB, Heimbürger O, Stenvinkel P. What are the causes of protein-energy PEW in chronic renal insufficiency? Am J Kidney Dis 2002;39:422-5.

8. Canada-USA (CANUSA) Peritoneal Dialysis Study Group. Adequacy of dialysis and nutrition in continuous peritoneal dialysis: association with clinical outcomes. J Am Soc Nephrol 1996;7:198-207.
9. Yan X, Yang X, Xie X, Xiang S, Zhang X, Shou Z, et al. Association between comprehensive nutritional scoring system (CNSS) and outcomes of continuous ambulatory peritoneal dialysis patients. Kidney Blood Press Res 2017;42:1225-37.

10. Chung SH, Linholm B, Lee HB. Influence of initial nutritional status on continuous ambulatory peritoneal dialysis patient survival. Perit Dial Int 2000;20:19-26.

11. Nazar CM. Significance of diet in chronic kidney disease. J Nephropharmacol 2013;2:37-43.

12. Wang AY, Sea MM, Ho ZS, Lui SF, Li PK, Woo J. Evaluation of handgrip strength as a nutritional marker and prognostic indicator in peritoneal dialysis patients. Am J Clin Nutr 2005;81:7986.

13. Mehrotra R, Kopple J. Nutritional management of maintenance dialysis patients: why aren't we doing better? Annu Rev Nutr 2001;21:343-79.

14. Olivares-Gandy HJ, Domínguez-Isidro S, López-Domínguez E, Hernández-VelázquezY, Tapia McClung $\mathrm{H}$, Jorge de-laCalleja. A telemonitoring system for nutritional intake in patients with chronic kidney disease receiving-peritoneal dialysis therapy. Comput Biol Med 2019;109:1-13.

15. Dombros N, Dratwa M, Feriani M, Gokal R, Heimbürger O, Krediet R, et al; EBPG Expert Group on Peritoneal Dialysis. European best practice guidelines for peritoneal dialysis. 8 Nutrition in peritoneal dialysis. Nephrol Dial Transplant 2005;20 Suppl 9:ix28-ix33.

16. Toigo G, Aparicio M, Attman PO, Cano N, Cianciaruso B, Engel B, et al. Expert working group report on nutrition in adult patients with renal insufficiency (Part 2 of 2). Clin Nutr 2000;19:281-91.

17. Clinical practice guidelines for nutrition in chronic renal failure. K/DOQI, National Kidney Foundation. Am J Kidney Dis 2000;35(6Supp12):S1-140.

18. Ikizler TA, Cano NJ, Franch H, Fouque D, Himmelfarb J, Kalantar-Zadeh K, et al. Preventionand treatment of protein energy wasting in chronic kidney disease patients. International Society of Renal Nutrition and Metabolism. Kidney Int 2013;84:1096-107.

19. Eustace JA, Coresh J, Kutchey C, Te PL, Gimenez LF, Scheel $\mathrm{PJ}$, et al. Randomized double- blind trial of oral essential amino acids for dialysis-associated hypoalbuminemia. Kidney Int 2000;57:2527-38.

20. González-Espinoza L, Gutiérrez-Chávez J, del Campo FM, Martínez-Ramírez HR, Cortés-Sanabria L, Rojas-Campos E, et al. Randomized, open label, controlled clinical trial of oral administration of an egg albumin-based protein supplement to patients on continuous peritoneal dialysis patients. Perit Dial Int 2005;25:173-80.

21. Moretti HD, Johnson AM, Keeling-Hathaway TJ. Effects of protein supplementation in chronic hemodialysis and peritoneal dialysis patients. J Ren Nutr 2009;19:298-303. 